\title{
Overall Review of Seismic Wave Affected on Gravity Dam
}

\author{
Asmaa Abdul Jabbar Jamel*, Raad Hoobi Irzooki, Ahmed Al-Obaidi \\ College of Engineering, Tikrit University, Salah Al Deen 34001, Iraq
}

Corresponding Author Email: ms.asmaajameel@tu.edu.iq

https://doi.org/10.18280/ijdne.160402

Received: 13 July 2021

Accepted: 10 August 2021

\section{Keywords:}

seismic, gravity dam, damage, hydrodynamic, stress

\begin{abstract}
Under seismic activity, gravity dams may crack and slide, causing damage to their bodies, as well as losing structural strength and rigidity. Investigating the factors that affect seismic waves on the stabilization of gravity dams is focused on reviewing the most significant previous literature in the present study. The seismic that causes damage starts at the gravity dam's heel and progresses upstream; this damage was not affected by the type of foundation of gravity dam, not even material damping. Still, it was noticeably affected within the different frequencies and amplitudes. In contrast, the sliding is governed by the direction of the forces generated at a lower frequency value. Also, the maximum hydrodynamic pressure was observed beyond peak ground acceleration value, where its distribution was almost linear at $25 \%$ of reservoir depth, as the remaining lower part (represented by $75 \%$ of reservoir depth) shows a nonlinear inclination.
\end{abstract}

\section{INTRODUCTION}

Dams are water-holding structures that may be used for several reasons, including generating electricity, storing irrigation water, preventing flooding, and more. Among the most significant forms of dams is the concrete gravity dam, which is a massive construction. As a result, the potential of being subjected to seismic waves and being harmed by them is possible.

As a result, when gravity dams are subjected to earthquakes, they must be built to satisfy strict statutory standards in order to ensure a minimal degree of safety and security. So while, seismic actions overall are tested and constructed to be Operating Basis Earthquake (OBE), which is an earthquake that can be generally believed during the dam's service period (144-year return period with a design life of up to 100 years) as well as the dam functional requirement associated with this earthquake will show minor damage or no damage, with no intrusion of irradiation [1]. Furthermore, a Max Design Earthquake (MDE) is seismic with maximum loads. During this sort of earthquake, the prerequisites for dam operation include no disastrous breakdown of function, such as uncontrolled reservoir releases. Finally, the strongest earthquake, known as the Maximum Credible Earthquake (MCE), may be reasonably predicted to strike dams, according to geology and seismic data $[1,2]$.

The earthquake's effect is equal to speeding base transfer in the wave's present direction. Earthquakes commonly create horizontal (h) and vertical (v) acceleration components. Also, during the earthquake acceleration, there are usually some high-frequency values, which are recorded as the peak ground acceleration (PGA) [3]. The increased pressure of flowing water on the front side of the dam during seismic is known as a hydrodynamic force [4-6]. To prevent severe structural damage as well as post-earthquake calculations for static loads and after-shock excitations, are used to detect overstressed areas that may fracture [1].

\section{DATA COLLECTION}

During earthquakes, dams with large reservoirs will displace the ground, causing the dam to rupture. The earthquake induces waves of varying wavelengths that can shake the ground in all directions, causing gravity dams to fail $[1,2]$.

The dam can crack or slip under the impact of high-intensity to moderate-intensity earthquakes, causing damage to its body, strength, and rigidity. The constant damage mechanics of the dam body is a useful tool for correctly modeling the deterioration of a concrete gravity dam's mechanical properties.

The dynamic response of concrete gravitational dams to seismic force can be influenced experimentally using various instruments and equipment. Some of the previous research listed in Table 1 used various approaches to investigate gravity dams and their effects on earthquakes in particular. For their study, the majority of these experiments used computer programs based on the finite element model, while others used table vibration testing experimentally. The effect of earthquakes on the size of the stresses produced within the gravity dam body, the amount of damage, and the horizontal displacement of the dam body were studied in these studies [7], as well as the response of the dam, the foundation, and the water interaction. Also, hydrodynamic pressure and the buildup of lifting pressure under gravity result from earthquakes, causing the dam to slip on its foundation (see appendix).

\section{DATA ANALYSIS}

\subsection{Damage inside gravity dam}

The rupture of the dam is caused by a change in the dam model's physical characteristics and the interaction between these physical characteristics and seismic characteristics, 
leading to damage in the gravity dam body [8]. The most significant item to check for when determining the safety factor of the gravity dam's body is damage produced by the gravity dam body, which is indicated by fractures. Because the effect of earthquakes causes the weaknesses, the gravity dam may fall, resulting in the loss of life and property downstream of the gravity dam. When earthquakes occur, tensile stresses form and dissipate throughout the dam's body, as these stresses should not exceed the dynamic tensile strength of concrete [9].

Because it's critical to use an analysis that works to determine the extent of the dam's reactions to these ground motions, many studies have looked into it and discovered that the damage caused within the gravity dam's body used to have a varied set of risks. The damage within the gravity dam's body begins at the heel, extends over the upstream side of the dam, and then continues to the downstream side, according to the investigators [10-13]. Despite the presence of an extensive series of cracks, energy dissipated within the dam's body due to high seismic waves is sometimes within 3-5 seconds. Since there was hazard along the front and up and down parts of the dam, singular cracks have been the influential just at high earthquakes, leading to the separation of the top of the dam from the main section of the dam. Furthermore, when fractures reach the free surface, they typically develop slowly, indicating stress and strain waves.

According to Mansouri et al. [14, 15], the incidence of damages within the dam's body began at 3.18 seconds in the existence of water at the reservoir, but at 3.78 seconds in the situation of an empty reservoir. The damage begins at the heel and progresses to the domain of the gravity dam's body's variation in slope. As a result, the existence of water in the reservoir accelerated the release damage to the gravity dam's body; also, the fractures at the heel of the empty reservoir had a secondary impact compared to the full reservoir. The researcher highlighted that when the combination within (foundation - dam - reservoir) is included, the damage seems to be greater at the heel than when the model employed is merely the connection with (dam - foundation) or (dam reservoir) [6, 16], as illustrated in Figure 1.

Also, when the fractures in the dynamic process were compared to the stable position, it was discovered that the appearance of fractures upstream of the gravity dam remained just under $0.1 \mathrm{~mm}$ micro fracture while exerting hydrostatic pressure. While the researcher demonstrated that when the highest tension stress at the heel is above the allowed maximum tolerance stress of concrete, fractures look in weak sections of the gravity dam, like the heel, due to the absence of stiffness and the existence of fractures at the gravity dam's neck was critical to the gravity dam's safe operation when subjected to earthquakes [17-19].

When such an earthquake with $\mathrm{PGA}=0.365 \mathrm{~g}$ is applied, the researcher claimed that utilizing reinforcing enhances the capacity to tolerate cracking by 1.454 times more than when it is not strengthened, and so avoids fractures from penetrating the gravity dam's body soon and even risking to fall [19], see Figure 2.

Also, the researcher demonstrated that when utilizing the ABACUS 2D and 3D models to demonstrate the level of damages in a gravity dam, some breakdowns and damages could only be seen in 3D models, making the conclusions safer [20, 21].

Although studies found that increasing the amount of PGA substantially increased the damage and fractures within the gravity dam body and decreased the gravity dam's tolerance to earthquakes with increasing fractures, the fracture form had a major effect on gravity dam crack resistance. As a result, the crack's form must be thoroughly examined in order to determine the dam's stability [17, 19, 22-31].

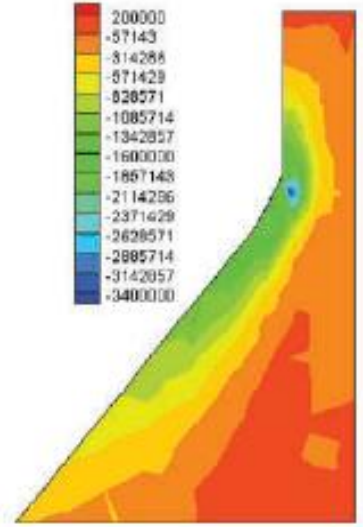

(i) Only dam

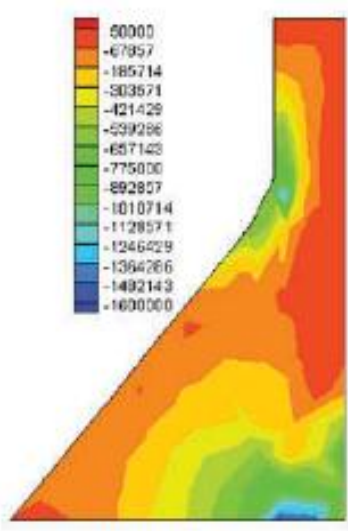

(ii) Dam-foundation

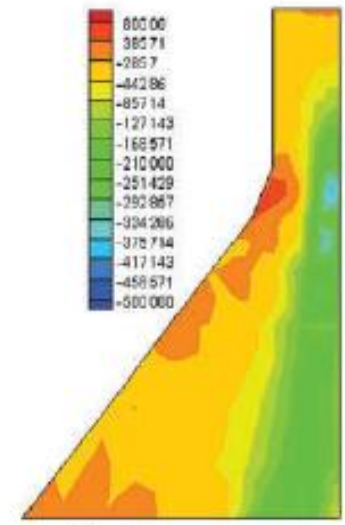

(ii) Dam-reservoir

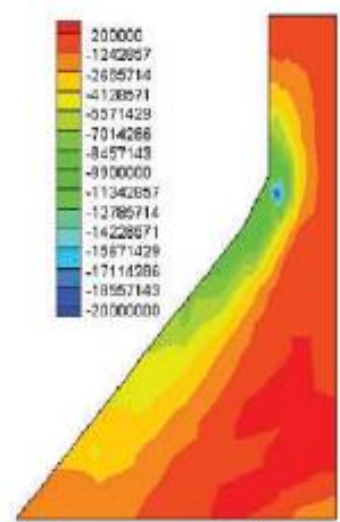

(iv) Dam-reservoir-foundation
Figure 1. Contour for minor principle stress of dam at 2.44 seconds [16]
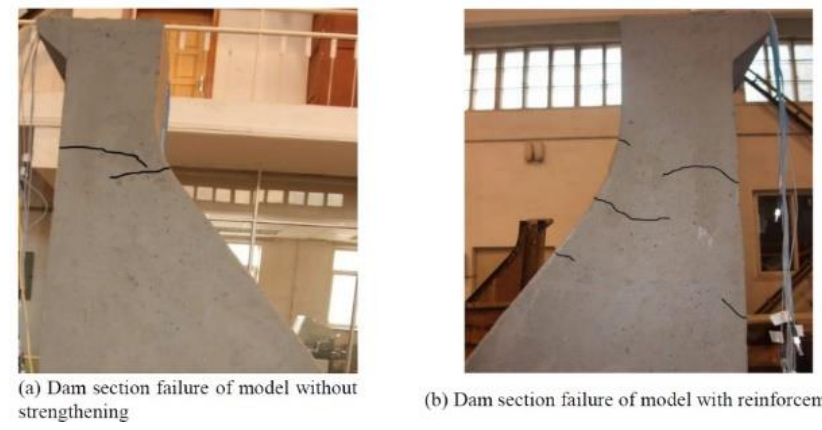

(b) Dam section failure of model with reinforcemen

Figure 2. Dam section failure patterns under the earthquake [19]

When an Operating Basic Earthquake (OBE) happens, fractures of up to $200 \mathrm{~mm}$ long and $0.3 \mathrm{~mm}$ in width emerge, according to Aldemir et al. [17]. Also, whenever the earthquake intensity is increased to Max Design Earthquake (MDE), the quantity of fractures increases to $550 \mathrm{~mm}$ long and $0.4 \mathrm{~mm}$ in width. The fracture size would rise by an extra 200 $\mathrm{mm}$ from the earlier situation after raising the value of the seismic wave to achieve the Max Credible Earthquake (MCE), and fractures might also form on the backside of the gravity dam, covering around $15 \%$ of the entire area of the gravity dam. 
As well, when 0.1 PGA more than $0.1 \mathrm{~g}$ and less than $0.5 \mathrm{~g}$ results in an increase in plastic energy demand to overall deformation energy, that would accelerate damage transmission, but when $\mathrm{PGA}>0.5 \mathrm{~g}$ leads to increase and development in plastic energy consumption to total deformation energy, that would function to brought the gravity dam's body nearer to break down [24].

The influence of the earthquakes on the dam body would've been different at each portion of it since the influence of such an earthquake on the top of the dam was just the least sensitive to the gravity dam's neck. Thus the fracture would spread widely throughout the neck $[18,11]$.

Furthermore, the researcher indicated that the maximum of earthquake acceleration at the heel and upstream slope was 5060 percent less in the case of the full reservoir due to water compressibility, and also that the quantity of acceleration at just the crest of the dam was 30 percent larger than the rock outcrop [18].

Although the researcher stated that gravity dams must not be placed on random soil inside the earthquake activity of PGA $=0.01 \mathrm{~g}-0.4 \mathrm{~g}$, which was $1-4$ on the Richter scale (I, II, III, IV, not felt, weak, and minor rocking) [25].

Furthermore, the researcher stated that the chance of major impacts inside the gravity dam's body is greater than $90 \%$ at MCE, but only 5\% at OBE, implying that such gravity dam's body would be stable under the effect of a minor earthquake in the event of OBE. In addition, when the severity of earthquakes rises, the dispersion of energy dissipation decreases [27].

Because crack creation is so important in assessing the dam's stability, the scientists [28] researched different forms of fractures and then obtained them by increasing the quantity of PGA in the koyna dam model. The initial cracking form resulted from a basic sliding of the top section of the fracture downstream along the fracturing, which resulted in fracture displacement and short-term stability. The second type of fracturing was discovered, and it has been caused by a rise in the quantity of PGA, which caused the gravity dam to fail.

The damage to the gravity dam caused by fracturing was an essential component in establishing its stability as a function of earthquakes, with the first fracture occurring at (PGA = $0.3458 \mathrm{~g})$ and the entire model failing at (PGA $=1.4176 \mathrm{~g})$, which would have been 5.65 times the gravity dam's maximum strength [11].

The section of the gravity dam with the highest downstream slope dissipated the most energy, and the explanation for this was that the size of the concrete material would be smaller at the greater slope [10], as seen in Figure 3.

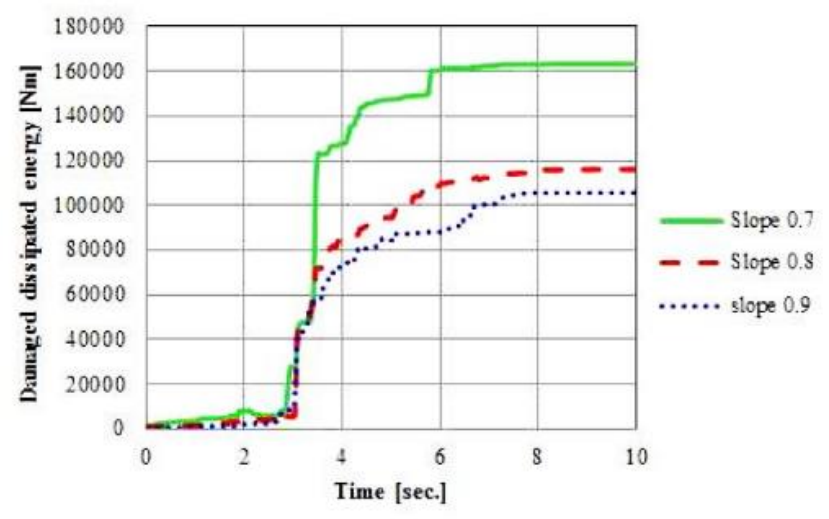

Figure 3. Damage dissipated energy for different slopes [10]
The energy dissipation causing damage within the gravity dam's body was affected by the size of the concrete material; and increase the height of gravity dam would lead to an increase in the size of this concrete material and thus an increase in energy dissipation, while the lower height of gravity dam was the least energy dissipation [10, 11, 32]. Also, [11] explained that along with the dam's height, the amount of acceleration would increase linearly with increasing gravity dam height and would decrease when the intensity of the earthquake was reduced.

The lowest tensile failure stress caused the most dissipation of fault energy within the gravity dam's body, resulting in tensile damage. The studies found that perhaps the associated concrete weakness by shear strain was 50 percent higher than the concrete of the gravity dam that was subjected to seismic waves [10, 33].

The damage within the gravity dam's body was not influenced by the kind of foundation soil or even substance damping, according to research $[13,34]$, so it was substantially impacted by the frequency of the seismic wave, as shown in Figure 4. This is consistent with [35], who indicated that the damping ratio was just a variable of the quantity of energy dissipated, including the stress magnitude. It was a changeable value with each time interval of the ground motion. It's also similar to [33] instance of wave motion fracture from the front face of the dam at the contact between the gravity dam and the base, in which the first soil had a greater density than the second. Also, according to Falco et al. [33], potential damping happens as a response of the plasticity simultaneously level on damping in the gravity dam's body in the case of nonlinear substance and for two damping values of $5 \%$ and $1 \%$. For both situations, though, the damping parameters had a reduced influence on the structure of the gravity dam. Also, it was discovered that if the gravity dam's body substance were nonhomogeneous, the total energy dissipation as a consequence of fracture would be the same.

In contrast, the energy dissipation in the damaged substance was lower, as the plastic actions of the substance provide a good impression of energy dissipation. The researcher employed 200 earthquake models and a gravity dam with a junction on the dam and lifted since these junctions helped to lower the displacement at the top of the gravity dam towards the downstream. Still, this displacement increased towards the upstream at the neck and decreased the incidence of slide [36].
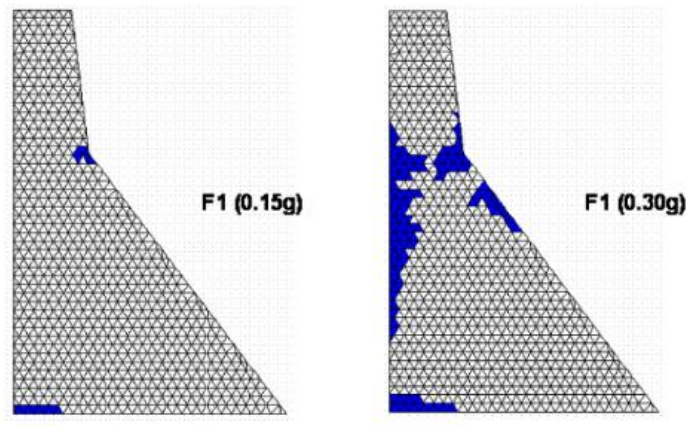

Figure 4. Damage prediction for two scaling levels of input motion [34]

The presence of strain is a key aspect in determining the extent of damage to the gravity dam's structure. The amount of strain at the base pier was greater than the rear pier, and the existence of the pier within the gravity dam body was the most 
stressed region, according to [11, 26, 37]. Furthermore, it was found that raising the magnitude of the earthquake would raise the quantity of strain, since raising the magnitude of the earthquake by $100 \%$ results in an increase in the strain of $481 \%$, but [26] notice that the strain value at the top of the gravity dam did not affect. Using the (FBG sensor) to discovered that the strain upstream was $1078 \mu \varepsilon$ and downstream was $1207 \mu \varepsilon$, indicating that the gravity dam would develop fractures and eventually open entirely as the earthquake intensity increased [11].

Falco et al. [33] stated that in the case of two influence seismic waves (time history recorded on October 30th 2016 by Savelli station, and time history recorded on August 24th 2016 by Amatrice station), the first wave would cause a crack on the downstream face of the gravity dam. However, the second seismic wave would cause a crack on the downstream side of the gravity dam, causing development damage incrementally and significantly different, as shown in Figure 5.

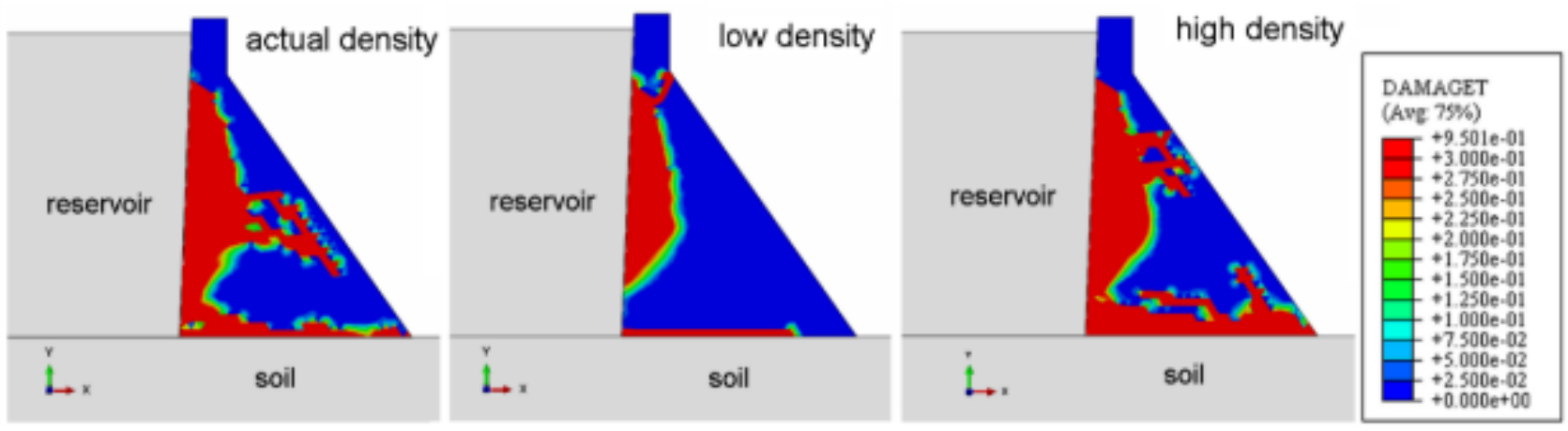

Figure 5. Damage on the dam, varying density [33]

\subsection{Displacement for gravity dam}

It was important to know the quantity of displacement in order to determine the probability of the gravity dam sliding on the base. The front displacement of the gravity dam was larger at full reservoir than when the reservoir was empty, according to a number of scientists [6, 10, 14-16, 38-46]. The possible explanation for this was due to the impact of hydrodynamic pressure, which was based on the use of numerous analytical models for different interactions between the surface of the items (dam, foundation, and reservoir), which would have an impact on the behavior of the gravity dam body where the horizontal displacement changes significantly. When an earthquake occurs with $(\mathrm{PGA}=0.5 \mathrm{~g})$ horizontally and $(0.35 \mathrm{~g})$ vertically, the highest displacement of the Koyna dam was $45 \mathrm{~mm}$ horizontally and $14 \mathrm{~mm}$ vertically, according to Mansouri et al. [14]. The research found that the gravity dam crest, when it reached a value of 7.5 $\mathrm{cm}$ during the earthquake depicted by the Koyna dam model, had a $50 \%$ chance of causing the highest displacement [47]. Also, the crest's highest displacement value was less than 26.5 $\mathrm{cm}$ [43]. Whereas researcher suggested, gravity dam pattern's highest displacement was $0.0293 \mathrm{~m}$ at 2.16 seconds towards the reservoir, which was a critical number in demonstrating the effect of contact (dam - reservoir) [42]. In addition, while employing joined connection, connection with interface element, and welded interaction for computer simulations, the differential in displacement at the full and empty gravity dam was somewhat different. When employing different forms of contact states for simulations with numerical analyzes, considerable variance in displacement would be seen.

Modifying the structure of the gravity dam body by raising concrete resistance at an empty reservoir did not affect top movement. Still, it did influence producing crack damage as a consequence of stress at the crest rather than a distribution throughout the dam body according to [10]. The investigators $[40,48]$ concurred on this impact. The displacement had a high accuracy when the rate of (base flexibility/concert flexibility) $(\mathrm{Ef} / \mathrm{Ec})$ was less than 2, and the sensitivity of the displacement decreased when the ratio of (base flexibility/concert flexibility) $\left(\mathrm{E}_{\mathrm{f}} / \mathrm{E}_{\mathrm{c}}\right)$ was less than 2. (2-5). There was no significant influence on displacement at an $\left(E_{f} / E_{c}\right)$ ratio larger than 5 , indicating a rise in the value of the base elasticity compared to concrete. As a result, in the case of an empty gravity dam reservoir, the horizontal displacement of the crest of the gravity dam increases with increasing base flexibility.

Although the researcher claimed that when the relation of $\left(E_{\mathrm{f}} / \mathrm{E}_{\mathrm{c}}\right)$ was set to 2, horizontal displacement was a significant number, there was no noticeable impact in the displacement of the dynamic state when compared to the static state for values greater than 2, as it's been detected that improving this fraction leads to a decline in the highest horizontal displacement of the gravity dam crest at the fixed base when using ANSYS. Compared to the (dam-foundation) model utilizing the SAP2000 software, the use of the fixed base of gravity dam results in lower results for the greatest top displacement [13]. Using base flexibility in numerical would considerably enhance the natural frequency throughout vibrational modes, which corresponds to [40]. Furthermore, while utilizing overflow and non-overflow monoliths at complete contact, the highest horizontal displacement of the dam top was identical (dam-reservoir-base). With a horizontal earthquake imposed on the Koyna dam, Mansouri et al. [14] stated that the effect of horizontal displacement produced for the empty reservoir was 37 percent less than the displacement produced for the filled reservoir. Still, for the vertical component earthquake, the vertical displacement was 28 percent less at the full reservoir, consistent with researchers' conclusions [6, 10, 3844]. During the study, deformation of gravity dams occurs as a result of a dynamic load. It was noticed that horizontal displacement of dams was an essential aspect that generated various horizontal displacements. Throughout the study of deformation, the dam would go through several modes. The form modes were discovered by examining natural frequencies in combination with these various modes throughout time. There was frequently a small variance in the natural frequencies from every mode. The displacement of the gravity dam changes with each frequency due to these distinct modes, 
making decisions in various shape modes problematic $[16,40$, $49,50]$. The researcher found that the initial occurrence of the deformation mode for the (dam - foundation) system was 0.57 seconds, which was greater than the 0.25 -second dam with a fixed base approach [51].

As the researcher observed using the concepts analyzed, the reservoir had the highest basic frequency when compared to the (dam -base) method alone, and thus the (dam - basereservoir) had the smallest basic frequency while (dam reservoir) had the highest, affecting the displacement values [16]. The horizontal displacement top was measured at the frequencies $14-16 \mathrm{~Hz}$ and $24-28 \mathrm{~Hz}$ by Phansri et al. [29] using models of gravity dams, the first with a compressive resistance of $0.317 \mathrm{Mpa}$ and the second with a compressive strength of 0.317Mpa. When utilizing the second model, which has a compression resistance of $0.399 \mathrm{Mpa}$, the displacement was measured at a frequency of $14 \mathrm{~Hz}$ as well as at a considerable amplification of 24-28 Hz. Zappitelli et al. [10, 40, 48] concurred that any modification in the material of the gravity dam body had no substantial effect on displacement. A number of researchers demonstrated that increasing the earthquake's severity from mild to medium and severe increased the crest's horizontal displacement [13, 17, 22, 39, $45,52,53]$, and studied demonstrated that using Operational Basis Earthquake (OBE) for the 1/75 scale Melen dam model resulted in displacement smaller than $0.05 \mathrm{~mm}$. However, increasing the magnitude of the earthquake to the Maximum Design Earthquake (MDE) resulted in a 14.8 percent increase in the dam's crest displacement. Also, the Maximum Credible Earthquake (MCE) level was five times higher $(370 \%)$ than the MDE level and nearly three times higher (290\%) than the MDE level [17].

The researcher demonstrated that the influence of a vertical earthquake for an unfilled reservoir on the horizontal displacement of the gravity dam top was significant at a Richter scale of 9.9. Still, at a Richter scale of 6.8, the displacement was only $2 \mathrm{~cm}$ [45], consistent with other researchers [13, 17, 22, 39, 52].

The researcher found that the lowest displacement was measured at 6.5 on the Richter scale, and the maximum displacement was reported at 9.9 on the Richter scale at full reservoir conditions [45]. At the effect of strong earthquakes, the highest rate in the horizontal displacement of the top was reported at over $50 \%$, which is consistent with [13, 17, 22, 39, 52].

The horizontal displacement of the gravity dam top under the effect of the vertical earthquake did not alter as a result of the vertical earthquake portion, according to [5]. This is because the horizontal portion mostly influences the change in water on the upstream side of the gravity dam. When the reservoir was half-filled in the storage capacity, an increase in horizontal displacement of about $7.7 \mathrm{~cm}$ was noted when the Richter scale was 9.9, indicating that rising the horizontal displacement raised the height of water in the reservoir. Still, the quantity of displacement was not significant at some ground motions. In general, as the amount of water in the reservoir rises, the quantity of hydrostatic force rises, generating a hydrodynamic force that raises the horizontal displacement of the top [45] and in agreement with the result $[13,17,22,39,52]$.

Since the dam portion would have been at a height to induce tensile damage near the crest of the gravity dam, Zappitelli et al. [10, 39] found that displacement quantity was a major impact for gravity dams with a greater downstream slope. The elevation of the gravity dam had an impact on the horizontal displacement of the gravity dam top, according to Zappitelli et al. [10, 32, 54, 55]. The gravity dams with the greatest displacement value at the maximum height were the most resistant to bottom limitations, which was because the upper section of the dam was subjected to a bigger impact.

In addition, Sevim [32] had detailed the influence of the gravity dam's base width/height $(\mathrm{L} / \mathrm{H})$, observing that as $\mathrm{L} / \mathrm{H}$ increased, the horizontal displacement value reduced since displacement rises with height dam elevation. The displacement would be reduced by 65 percent if the $\mathrm{L} / \mathrm{H}$ ratio was reduced from 0.25 to 1.25 , while the quantity of the largest horizontal displacement of the crest would be increased by 22 percent if the $\mathrm{L} / \mathrm{H}$ ratio was changed from 0.25 to 0.5 . This is consistent with $[10,32,45,54]$, who found that raising the $\mathrm{L} / \mathrm{H}$ reduced the displacement (see Figure 6).

The researcher showed that raising the magnitude of the earthquake had a 0.04 percent variation in the settling of the gravity dam's body from its stable condition for $\mathrm{PGA}=0.1 \mathrm{~g}$ and elevation of the water/height of the dam $\left(h_{w} / h\right)=0.25$. As the height of the gravity dam was increased to $\left(\mathrm{h}_{\mathrm{w}} / \mathrm{h}\right)=0.95$, there was a 0.16 percent rise in the quantity of settling [55].

A more difficult instance of knowledge, where the research demonstrated that the more complicated rock layers contributed to greater potential resonance, but that the complexity of these layers might not be a crucial component in estimating the danger level for a (dam - foundation) system. The critical situation was also characterized as the greatest forceful amplitude and the largest displacement. The analyses also demonstrated that when the weaker layer was positioned close below the dam, the (dam - foundation) system was not realized. As a result, the weak layer underneath the dam had a critical depth because it had the largest impact on damping [46].

This is in accordance with the finding obtained by Mohsin [25] when relative density $\mathrm{R}_{\mathrm{d}}=60 \%$ and $85 \%$ of the foundation were used. It was also discovered that when the relative density of the soil increases, the horizontal displacement of the top caused by the earthquake decreases due to the material's flexibility.

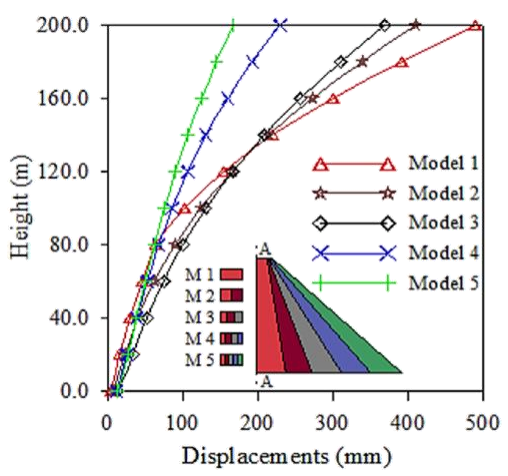

Figure 6. Maximum horizontal displacements on a-a section of each gravity dam models [32]

\subsection{Sliding safety for gravity dam}

The development of the slide results from a horizontal force greater than the friction resistance [56]. Gravity dam collapse can happen during the slide or due to collapse caused by many factors, such as crushing. The forces' direction created and affected the gravity dam, which was of varying frequencies 
and amplitudes, determined this breakdown. The researcher discovered that a slide at the gravity dam's base might result in low amplitude for a transient load. When the amplitude rises, cracks form that transition from sliding to cracking, causing encroachment in the mode $[12,45]$. As the ground vibrations rise, the slide transforms into a sliding-crushing dominated mode. It had slipped under the effect of the laboratory model's seismic wave [17].

Additionally, researchers have shown that raising the friction coefficient between the intermediate layers enhances the continuity of the dam by sliding since raising this value prevents the surface from sliding and increases the chance of sliding, resulting in breaking [28, 51]. However, another researcher discovered that utilizing a friction coefficient less than 0.8 increased the sliding throughout this investigation [28]. The researcher also stated that if the shear strength reduction ratio $(\mathrm{K})$ is increased to a value between 1.136 and
1.203, dynamic horizontal movement will change. When $\mathrm{K}$ achieves 1.203, dynamic horizontal displacement will seem at the heel and top with a substantial significant change that is non-directional and irreversible [51], as shown in Figure 7.

The researcher said that raising the horizontal component of earthquake improvements might diminish the factor of safety and overturning, as well as, the safety factor in a dynamic condition would be around $50 \%$ less in a static condition [23, $45,55]$. The researcher showed that when the gravity dam on a very stiff clay foundation and exposure to earthquake PGA $=0.22 \mathrm{~g}$ and $\mathrm{h}_{\mathrm{w}} / \mathrm{H}$ increases (due to the rise in the water level), the failure due to sliding occurs with a lower earthquake value, so sliding occurs before the overturning occurs [55]. In the case of $\left(\mathrm{h}_{\mathrm{w}} / \mathrm{H}\right)=0.25$, the overturning would occur at PGA $=0.65 \mathrm{~g}$, and the sliding at $0.55 \mathrm{~g}$, see Figure 8. Opan [45] had shown that increasing $(\mathrm{L} / \mathrm{H})$ increases the factor safety against sliding.
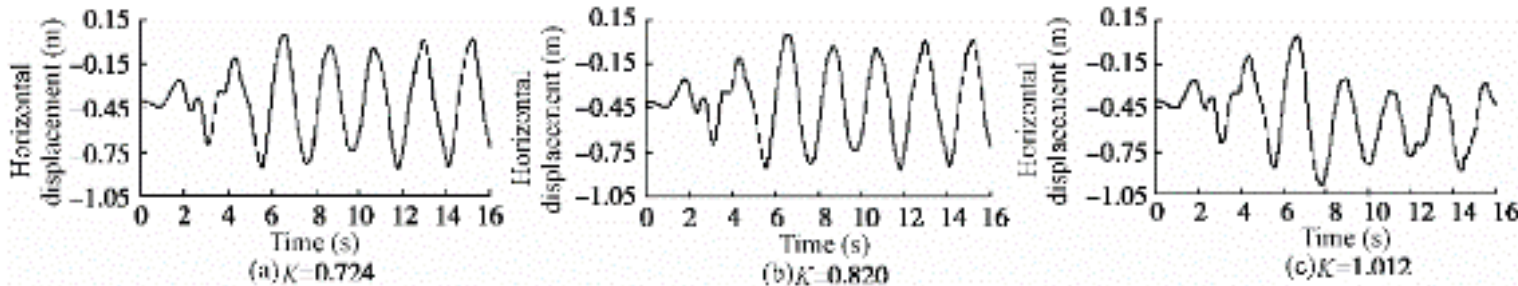

Figure 7. K-Displacement curve at crest [51]

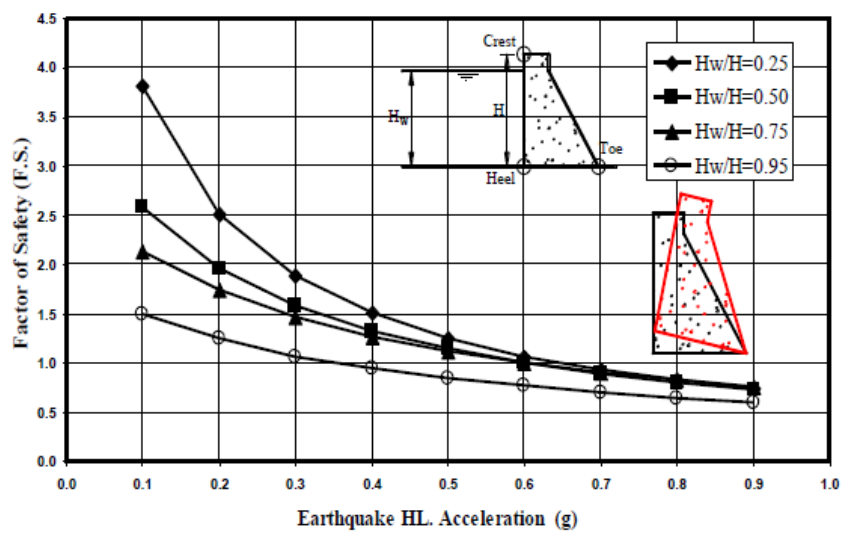

Figure 8. Factor of safety against overturning [55]

\subsection{Hydrodynamic pressure}

Additional pressure is created after an earthquake due to water motion at the upstream gravity dam, and a similar scenario occurs when waves impinge on the offshore jetties. During horizontal seismic waves, hydrodynamic pressure would be generated on the dam's face and in the reverse way of the earthquakes, resulting in alternating compressive and tensile strength cycles. (excessive stress can cause cavitation) [5].

Many researchers have looked at the impact of earthquakes. Mohsin et al. [5, 6, 13, 48, 57] shown that hydrodynamic pressure was significant and varied with time throughout the earthquake and across the height of the dam. The highest hydrodynamic pressure was measured, exceeding PGA due to the build-up of strains throughout the earthquake's transportable. It could be seen that the highest hydrodynamic pressure often does not happen to close the gravity dam toe, but rather anywhere along with the dam's height during high earthquake intensity. The amount of hydrodynamic pressure along the upstream face was significant and was dependent on the reservoir's depth.

Because the biggest value in the model happened around 2.16 seconds [6], and as described, it occurring around 2.78 seconds, peak hydrodynamic pressure occurs 5 seconds after seismic events [16].

The researcher reported that when variations $\left(E_{f} / E_{C}\right)$ were applied to the hydrodynamic, the results are consistent, implying that hydrodynamic is primarily determined by the height of the dam and the magnitude of the earthquake, with the presence of the foundation having no significant impact on the amount of hydrodynamic [13, 48]. This was the reverse conclusion obtained by another researcher, who found that soil with $\left(\mathrm{R}_{\mathrm{d}}=60 \%\right)$ had a slightly higher hydrodynamic quantity than soil with $\left(\mathrm{R}_{\mathrm{d}}=80 \%\right)$, as a result of the reservoir water absorbing the wave that impacted the dam during the seismic [25].

According to the researcher, the hydrodynamic distributions were virtually linear at the top $25 \%$ of the reservoir level, while it was nonlinear at the rest $75 \%$ of the reservoir deep [13], see Figure 9. Because, the nonlinear manner of spreading hydrodynamic pressure through even does not get a distinct tendency. Furthermore, because the linear trend was around 96 percent of the hydrostatic pressure, it was discovered that hydrodynamic construction might be estimated with a 15-25 percent rise in the hydrostatic pressure value of the hydrostatic pressure at the height of the gravity dam. This was in agreement with another researcher, which found that hydrodynamic pressure exceeds hydrostatic pressure, with the highest value of $251.61 \mathrm{Kpa}$ at the heel in 0.42 seconds. Hydrodynamic pressure also had positive and negative values when contrasted to hydrostatic pressure, with around $90 \%$ of the hydrodynamic at the heel $[42,43,57]$. 


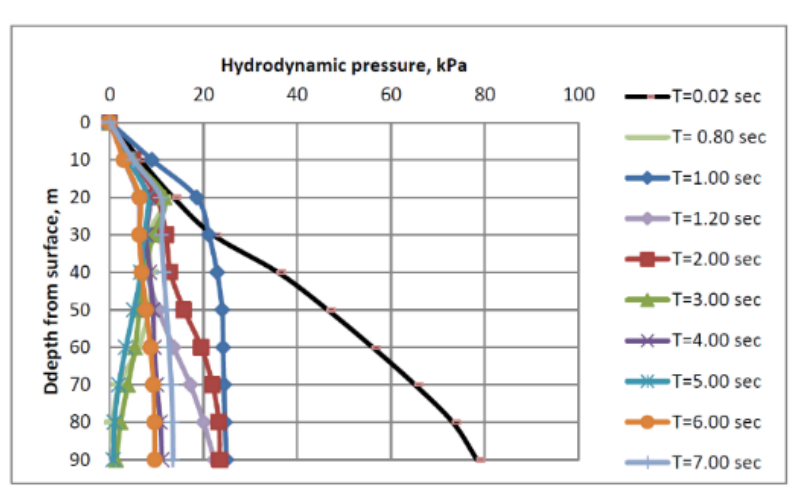

Figure 9. Hydrodynamic pressure distribution on upstream face at different times [13]

The researcher found that the heel of the dam experiences around half of the highest hydrodynamic pressure, which was around 30kpa during the seismic [47]. Also, it is shown that the foundation's flexibility has a significant impact on the hydrodynamics of gravity dams. This factor must be considered when studying water projects under the effect of seismic.

\subsection{Uplift pressure under gravity dam}

The drainage of water underneath the dam through the foundation's fractures, pores, and fissures could result in a build-up of water flow underneath the dam's foundation [58].

The influence of seismic waves on uplift pressure is a measurement of the total hydrostatic pressure at the dams, according to researchers $[52,55]$. The water pressure would fluctuate due to a hydrodynamic action throughout seismic event. Still, the shift was not thought to help cause the rise or reduction in uplift pressure. However, throughout brief seismic events, the quantity of uplifting pressure underneath the dam and the rocky base would build-up, and the uplifting pressure could rise as the earthquake's severity increased.

Also highlighted that as the water level in the reservoir rises, the quantity of hydrostatic pressure on the gravity dam's base rises. Still, this growth is not the same as what occurs in a dynamic analysis. This implies that the rise in dynamics was not the same as the increase in the static state. The uplift pressure was measured at the minimum ratio of $(\mathrm{hw} / \mathrm{H})$, indicating that the quantity of uplift pressure would gradually decrease as the height of the water in the reservoir's tail increased [55].

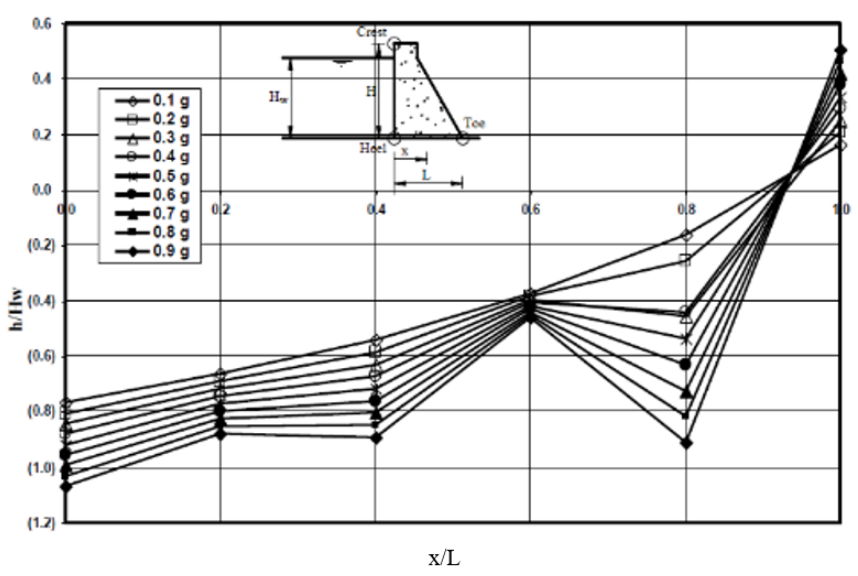

Figure 10. The relative uplift pressure for different earthquake horizontal acceleration components, $h_{w} / H=0.95$

[55]
For example, when using $\left(\mathrm{h}_{\mathrm{w}} / \mathrm{H}=0.25\right)$ would notice an increase in the amount of uplift pressure $26.3 \%, 57.9 \%, 84.2 \%$, $115.8 \%, 142.1 \%, 173.7 \%, 205.3 \%$ and $231.6 \%$ with increasing the horizontal earthquake PGA from 0.2 to $0.9 \mathrm{~g}$ of an increment of $0.1 \mathrm{~g}$. The uplift pressure decreases when increasing by about $21.1 \%, 50 \%$ and $52.6 \%$ with increasing $\left(\mathrm{h}_{\mathrm{w}} / \mathrm{h}\right)$ from $0.5-0.75-0.95$ for an earthquake of $(\mathrm{PGA}=0.1 \mathrm{~g})$, see Figure 10.

\subsection{Stress in gravity dam}

Several studies had aimed to investigate the performance of gravity dams under the impact of seismic force, as the large structure presented by the gravity dam would be subjected to large pressures dispersed differentially inside the gravity dam's body when subjected to seismic activity. As a result, the review found that the concentration of stresses should be thoroughly investigated in order to ensure the gravity dam body's safety [59]. Earthquake effects on gravity dam, Sevim et al. [32, 49] revealed that stresses grow within the gravity dam from top to bottom in the event of a fixed foundation, where researcher said that the formation of hydrostatic pressure $0.55 \mathrm{kN} / \mathrm{m}^{2}$ corresponds to the largest stress in this exact scenario of $4.9 \mathrm{kN} / \mathrm{m}^{2}$ [49]. As generally, research has shown that when concrete dams are subjected to dynamic loads, they create stresses that must be analyzed in order to evaluate if the gravity dam can safely sustain these stresses. The largest and minimum stresses created for each mode shape were different, and the cause for this acceleration was the shift over time. In order to determine if the dam can bear this dynamic load, the largest produced stress must be compared to the allowed material's stress capability. The stresses induced were within the acceptable limits to prevent the development or development of failure by crushing, as shown by the outcomes of $[21,32,49,50,60]$. The researcher employed programs based on the finite elements of $(2 D+3 D)$ analysis since the findings derived for stresses using (2D) were highly significant [20,42]. These outcomes revealed that the lower stress was generated in the heel, as studies indicated that the highest stress within the heel was 2.16 seconds. The toe has been subjected to various stresses ranging from compression to tension, whereas the majority of stress outcomes at the heel were compression stresses [21, 32, 42, 47, 61].

The researcher found that the highest yield stress was at the heel, with a value of $5291.8 \mathrm{kPa}$, and the lowest yield stress was at the toe, with a value of $806.344 \mathrm{kPa}$ at $2.16 \mathrm{sec}$ [42], as seen in Figure 11. In addition, Khiavi [43] said that in the full reservoir, the chance of developing the 1 st principle stress at the heel is $80 \%$, and the chance of development of the $3 \mathrm{rd}$ principle stress at the toe is $80 \%$.

The researcher noticed that the greatest total stress occurring through time step was beyond the occurrence of PGA, and the occurrence of the maximum principal stress changes with changing the coupling interaction used in the analysis [5, 16].

While researchers revealed that the largest stress throughout the study occurred when employing the (reservoir - dam base) interface, this highlights an essential value that must be considered during the earthquake study of the dam, namely the base and reservoir flexibility [16, 23].

Researchers found that the principal stress varies somewhat when the dam's height varies [16, 38], as demonstrated by another researcher, who found that raising the dam's height resulted in a $2 \%$ increase in stress. According to the influence 
of hydrodynamics [16], it has been demonstrated by studies that a full reservoir produces a larger stress value than an empty reservoir [38, 46]. Furthermore, [18] stated that the compressibility of water would reduce $10-20 \%$ of the amount of tension but that this number would have no meaningful effect on the stress at the toe as a consequence of the compressibility of the conserved water.

The influence of the vertical motion of the seismic, which behaved similarly to horizontal component seismic activity in terms of the emergence of maximum stresses at the heel for unfilled reservoirs, was shown in the ref. [61]. The horizontal component earthquake did not provide notable distribution findings in terms of stress distribution within gravity dams. The influence on peak top dam movement was less than the horizontal portion seismic.

In regards to increasing the size of the concrete block, which decreases the principal stress, researchers found that increasing the length of the dam's base operates to reduce the number of stresses, and adding a slope at the upstream gravity dam or soft curve would solve the effects of stress concentration $[32,62]$.

Several researchers demonstrate that the stresses would rise as the seismicity intensity increased, with [52] explaining that the stresses will also increase by $50 \%$ when the earthquake moved to Zone III from Zone II, $60 \%$ when it moved to Zone IV from Zone II, $75 \%$ to Zone V from Zone II, $20 \%$ to Zone IV from Zone III, and 37.5 percent to Zone V from Zone II [13, $52,55,53]$.

The stresses created by the dead load are 2-3 times smaller than the stresses created by earthquakes, according to Zeydan [42]. At the same time, the researcher found that when two types of foundations were employed, the first soil with relative density $=60 \%$ focused stress at the heel and toe. The amount of stress increased to $70 \%$ in the second example while employing soil relative density $=80 \%$, compared to the first example of the foundation soil [25].

The results connected with the seismic projection model on concrete dams and various specifications and earthquakes were estimated using the Artificial Neural Network technique (ANN) by researchers [39, 59, 63-65]. The derived findings revealed a substantial convergence in the FEM and the ANN; this analysis considers a significant number of inputs to extract findings. The data set was sometimes above 30,000, and the values were randomly produced to discover stable findings, and the research would produce findings quickly. Using 900 distinct models by ANSYS, Al-Suhaili et al. [66] discovered that the ratio of agreement between inputs and outputs was $97.8 \%, 99.7 \%$.

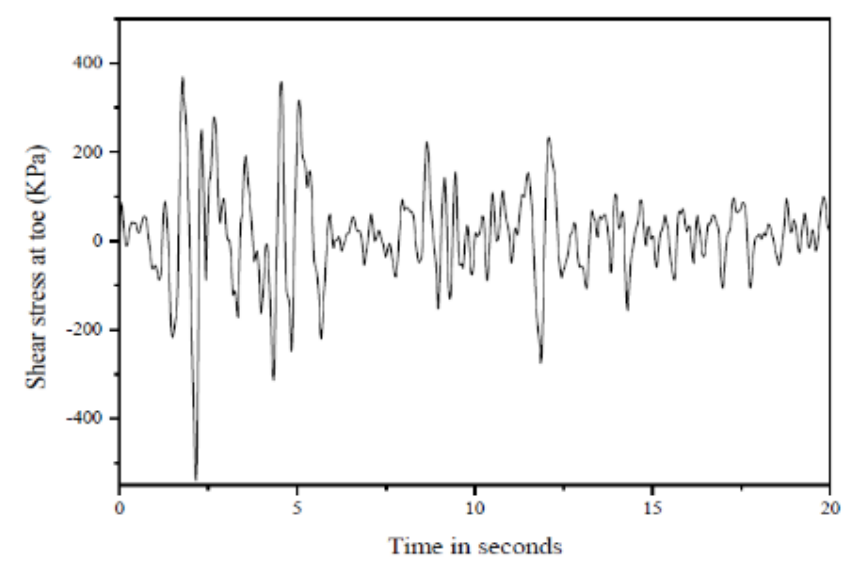

Figure 11. Time history of vertical stress at dam toe [42]

\section{CONCLUSION}

The present paper investigated information gathered by various scholars concerned with the effects of various seismic intensities on dam safety and damage and the spread of stresses, hydrodynamic pressure, and uplift pressure inside the gravity dam's structure. In addition to simulating that used a shaker table, most research focused on modeling using finite elements for gravity dams, which allowed it to depict the base body and interactions within (dam, reservoir, and base). The most relevant data obtained, on the other hand, is defined as follows:

- Damage to its gravity dam's structure occurs at the heel, then spreads upstream and downstream across the dam's upstream side

- By considering the connection among (foundation - dam - reservoir), the damage seems to be larger at the heel than that when merely considering the contact involving (dam - base) or (base - reservoir).

- Raising the quantity of PGA could dramatically increase the quantity of damage and fractures within the gravity dam structure.

- The gravity dam with the steepest downstream slope dissipated the most energy.

- The type of base soil of the dam, nor even material damping, did not affect the damage inside the gravity dam's structure, but the seismic wave frequency affected.

- The first wave crack in the upstream side of the gravity dam would have been the consequence of two simultaneous seismic waves. Still, when the second seismic wave comes, the crack would begin to form at the downstream side of the gravity dam, causing progressive damage sequentially and differentially.

- In the case of an empty gravity dam reservoir, the horizontal displacement of the top rises as the foundation's flexibility grows.

- When contrast to the (dam-base) model, the fixed base finite element model of gravity dam yields smaller incomes for the highest crest movement.

- Due to the flexibility of the soil with significantly higher density, the horizontal movement of the top created by the seismic reduces as the relative density of the soil increases.

- The forces' vector created and affected the gravity dam, varying frequencies and amplitudes dictated sliding failure. It also happens with a smaller seismic; thus, the slide begins earlier overturn.

- At PGA, the greatest hydrodynamic pressure was found. The highest hydrodynamic pressure does not usually occur around the gravity dam toe throughout a seismic event but rather along the dam's elevation. In addition, the spread was almost linear at the top $25 \%$ of the reservoir depth, as well as at the bottom $75 \%$.

\section{RECOMMENDATIONS}

- Extensive experimental investigations on the effects of seismic events on gravity dam models are required.

- By adding extra supports to the gravity dam's base, realistic investigations have shown that the geometrical portion of gravity dams is more stable against sliding and overturning.

- To demonstrate the best performance in terms of stress and strain activity, rely on contact modeling of gravity dams, foundations, and reservoirs. 


\section{REFERENCES}

[1] US Army Corps of Engineers. (2007). Earthquake design and evaluation of concrete hydraulic structures. Engineer Manual. 1110-2-6053, Washington.

[2] Segura, R., Bernier, C., Monteiro, R., Paultre, P. (2019). Seismic fragility assessment of concrete gravity dams in eastern Canada. Earthquake Spectra, 35(1): 211-231. https://doi.org/10.1193/012418EQS024M

[3] Wieland, M., Malla, S. (2000). Earthquake safety of an arch-gravity dam with a horizontal crack in the upper portion of the dam. In Proc. 12th World Conf. on Earthquake Engineering, Auckland, New Zealand.

[4] Vani, M., Babu, K. (2017). The effect of reservoir compressibility on the earthquake performance of gravity dams. International Journal of Advances in Mechanical and Civil Engineering, 4(5): 57-62.

[5] Dey, A., Sawant, M.B. (2013). Seismic response of a concrete gravity dam considering hydrodynamic effects. APCOM \& ISCM, Singapore. 11-14th December.

[6] Zeydan, B.A. (2013). Seismic dam-reservoir interaction of concrete gravity dams. Conference: 9 th Symposium of ICOLD European Club IECS2013. Italy.

[7] Stehman Matthew, J.J. (2014). Advances in shake table control and substructure shake table testing. Ph.D. Thesis, Hopkins University, Baltimore, Maryland.

[8] Esmaielzadeh, S., Ahmadi, H., Hosseini, S. (2018). Damage detection of concrete gravity dams using Hilbert-Huang method. Journal of Applied Engineering Sciences, 8(235): 7-16. http://dx.doi.org/10.2478/jaes2018-0012

[9] Nayak, P., Maity, D. (2013). Seismic damage analysis of aged concrete gravity dams. International Journal for Computational Methods in Engineering Science and Mechanics, 14: 424-439. http://dx.doi.org/10.1080/15502287.2013.784380

[10] Zappitelli, M., Villa, E., Sáez, J., Rocco, C. (2014). Cracking development prediction in concrete gravity dams using concrete damage plasticity model. mecánica computacional. XXXIII: 909-921.

[11] Wang, M., Chen, J., Wei, H., Song, B., Xiao, W. (2019). Investigation on seismic damage model test of a high concrete gravity dam based on application of FBG strain sensor. Hindawi Complexity. https://doi.org/10.1155/2019/7837836

[12] Das, R., Cleary, P.W. (2013). A mesh-free approach for fracture modelling of gravity dams under earthquake. International Journal of Fracture, 179: 9-33. http://dx.doi.org/10.1007/s10704-012-9766-3

[13] Zeidan, B.A., Seleemah, A. (2018). Seismic stability analysis of concrete gravity dams. Conference: ICOLD, at: Veinna.

[14] Mansouri, A., Neshaei, M.A.L., Aghajany, R. (2011). Fracture analysis of concrete gravity dam under earthquake induced loads. J. Appl. Sci. Environ. Manage, $15(2)$ :

317-325. http://dx.doi.org/10.4314/jasem.v15i2.68515

[15] Shahir, M.E., Maity, D., Khasung, G. (2008). Effect of foundation-reservoir interaction on seismic behaviour of gravity dams. International Conference on Case Histories in Geotechnical Engineering Arlington, Virginia.

[16] Mandal, K., Maity, D. (2016). Transient response of concrete gravity dam considering dam-reservoirfoundation interaction. Journal of Earthquake
Engineering,

22(2):

211-233.

http://dx.doi.org/10.1080/13632469.2016.1217804

[17] Aldemir, A., Binici, B., Canbay, E., Kurc, O., Arici, Y. (2014). Pseudo dynamic test results of a concrete gravity dam. Tenth U.S. National Conference on Earthquake Engineering. Anchorage. Alaska.

[18] Banerjee, A., Paul, D., Dubey, R. (2014). Modelling issues in the seismic analysis of concrete gravity dams. Dam Engineering, XXIV(2).

[19] Wang, M., Chen, J., Fan, S., Shaolan, L. (2014). Experimental study on high gravity dam strengthened with reinforcement for seismic resistance on shaking table. Structural Engineering and Mechanics, 51(4): 663683. http://dx.doi.org/10.12989/sem.2014.51.4.663

[20] Torba, M., Dulińska, J., Boroń, P. (2017). Nonlinear performance of a concrete gravity dam under a moderate seismic shock. JVE International Ltd. Vibro-engineering Procedia, 13: 142-147. https://doi.org/10.21595/vp.2017.19057

[21] Shahir, M.E., Dhurvey, P. (2017). Stability analysis of concrete gravity dam for seismic loading in Afghanistan. International Journal of Engineering Technology Science and Research, 4(6): 507-512.

[22] Yamaguchi, Y., Hall, R., Sasaki, T., Matheu, E., Kanenawa, K., Chudgar, A., Yule, D. (2004). Seismic Performance Evaluation of Concrete Gravity Dams. 13th World Conference on Earthquake Engineering. Vancouver. B.C. Canada.

[23] Banerjee, A., Paul, D.K., Acharyya, A. (2015). Optimization and safety evaluation of concrete gravity dam section. KSCE Journal of Civil Engineering, 19: 1612-1619. http://dx.doi.org/10.1007/s12205-015-01390

[24] Zheng, X., Hao, J. (2019). Research on seismic assessment of gravity dam based on performance analysis. IOP Conf. Series: Earth and Environmental Science, 376: 012036. https://doi.org/10.1088/17551315/376/1/012036

[25] Mohsin, A.Z. (2015). Dynamic response of concrete gravity dam on random soil. International Journal of Civil Engineering and Technology (IJCIET), 6(11): 2131.

[26] Li, S., Alam, S., Issa, A.S., Alam, T., Austin, R. (2019). Comparative seismic performance of dams in Canada and China using numerical analysis and shake table testing. Conference: ICOLD Annual Meeting/Symposium. Ottawa. Canada.

[27] Ganji, H.T., Alembagheri, M., Khaneghahi, M. (2019). Evaluation of seismic reliability of gravity dam-reservoir in homogeneous foundation coupled system. Frontiers of Structural and Civil Engineering, 13(3): 701-715. https://doi.org/10.1007/s11709-018-0507-1

[28] Jiang, S., Du, C. (2012). Seismic stability analysis of concrete gravity dams with penetrated cracks. Water Science and Engineering, 5(1): 105-119.

[29] Phansri, B., Charoenwongmit, S., Yooprasertchai, E., Park, K., Warnitchai, P., Shin, D. (2015). An experimental study on shaking table tests on models of a concrete gravity dam. KSCE Journal of Civil Engineering, 142-150. http://dx.doi.org/10.1007/s12205014-1221-8

[30] Soysal, B.F. (2014). Performance of concrete gravity dams under earthquake effects. MSc. Thesis, Middle East Technical University. 
[31] Cai, Q. (2007). Finite element modelling of cracking in concrete gravity dams. Ph.D. Thesis. University of Pretoria.

[32] Sevim, B. (2018). Geometrical dimensions effects on the seismic response of concrete gravity dams. Advances in Concrete Construction, 6(3): 269-283. https://doi.org/10.12989/acc.2018.6.3.269

[33] Falco, A., Mori, M., Sevieri, G. (2019). Soil-structure interaction modeling for the dynamic analysis of concrete gravity dams. 7th ECCOMAS Thematic Conference on Computational Methods in Structural Dynamics and Earthquake Engineering, Crete, Greece. https://2019.compdyn.org/.

[34] Yamaguchi, Y., Hall, R., Sasaki, T., Matheu, E., Kanenawa, K., Chudgar, A., Yule, D. (2004). Seismic performance evaluation of concrete gravity dams. 13th World Conference on Earthquake Engineering. Vancouver, B.C. Canada.

[35] Souri, A., Mirzabozorg, H. (2018). Material damping evaluation in a typical concrete gravity dam. Ingegneria Sismica International Journal of Earthquake Engineering, 35(3): 121-138.

[36] Gavabar, S., Alembagheri, M. (2017). Probabilistic seismic demand analysis of jointed gravity dams. Conference: ICOLD.

[37] Issa, A.S., Alam, T., Austin, R., Alam, S., Seethaler, R., Taylor, J. (2018). Experimental and numerical investigation of a reduced scale dam utilizing $3 \mathrm{~d}$ printing $\&$ shake table analysis. CDA Annual Conference. Canada.

[38] Karabulut, M., Kartal, M.E., Cavusli, M., Coskan, S., Dursun, O. (2017). Investigation of concrete gravity dam behaviour considering dam-foundation-reservoir interaction. The Online Journal of Science and Technology. 7(2): 78-85.

[39] Joghataie, A., Dizaji, M. (2019). Nonlinear analysis of concrete gravity dams by neural networks. Proceedings of the World Congress on Engineering, 2.

[40] Elprince, M.R., Seleemah, A.A., Rashed, A.A., Zeidan, B.A. (2015). Seismic behavior of concrete gravity dams including dam-reservoir-foundation interaction. International Conference on Advances in Structural and Geotechnical Engineering, Hurghada, Egypt.

[41] Naseri, F., Khalkhali, A. (2018). Evaluation of seismic performance of concrete gravity dams under soilstructure-reservoir interaction exposed to vertical component of near-field earthquakes during impounding (case study: pine flat dam). J. Civil Eng. Mater., 2(4): 181-191.

[42] Zeydan, B.A. (2013). Hydrodynamic analysis of concrete gravity dams subjected to ground motion. Conference: 9th Symposium of ICOLD European Club IECS2013. Italy.

[43] Khiavi, M.P. (2016). Investigation of the Effect of Reservoir Bottom Absorption on Seismic Performance of Concrete Gravity Dams using Sensitivity Analysis. KSCE Journal of Civil Engineering, 20(5): 1977-1986. https://doi.org/10.1007/s12205-015-1159-5

[44] Çavuşli, M., Kartal, M. (2018). Earthquake behaviour of concrete gravity dams considering various interaction conditions. Conference: International Conference on Advances in Structural and Geotechnical Engineering, Egypt, 2.

[45] Opan, M. (2014). Effects of safety factors on the deflections in a concrete gravity dam. Journal of the South African Institution of Civil Engineering, 56(3): 2529.

[46] Yunwei, D., Monfared, K., Basaran, C. (2019). Effects of rock layering on dynamic response of a gravity dam. Geo-Congress. Earthquake Engineering and Soil Dynamics, http://dx.doi.org/10.1061/9780784482100.028

[47] Khiavi, M.P. (2017). Investigation of seismic performance of gravity dams using probabilistic analysis. Građevinar, 69(01): 21-29. https://doi.org/10.14256/JCE.1454.2015

[48] Zeidan, B.A. (2015). Effect of foundation flexibility on dam-reservoir-foundation interaction. Eighteenth International Water Technology Conference. IWTC18, Sharm ElSheikh.

[49] Reddy, M., Rajaram, C. (2017). Seismic analysis of concrete gravity dam. International Journal of Engineering Technology Science and Research, 4(8): 244-249.

[50] Rozaina, I., Hilfi, K., Insyirah, M. (2017). Seismic analysis of concrete dam by using finite element method. MATEC Web of Conferences, 103. https://doi.org/10.1051/matecconf/201710302024

[51] Wang, D., Zhang, L., Xu, J., He, M., Zhang, W. (2009). Seismic stability safety evaluation of gravity dam with shear strength reduction method. Water Science and Engineering, 2(2): 52-60.

[52] Tanooja, C., Rao, V. (2016). Design of gravity dam by concrete using seismic coefficient method in different zones. International Journal for Technological Research in Engineering, 4(4): 612-918.

[53] Deepika, M. (2017). Seismic behaviour and stability analysis of gravity Dam. International Journal of Advanced Science and Engineering Research, 2(2): 174185.

[54] Bendapudi, H., Ramancharla, P. (2018). Dams and Earthquakes. Conference: USMCA, India.

[55] Mowafy, M.H., Salem, M.N., Salem, T.N, Anwar, A.M, El Deeb, H.A. (2013). Seismic Performance of Concrete Gravity Dams. The Egyptian Int. J. of Eng. Sci. and Technology, 16(1). http://dx.doi.org/10.21608/eijest.2013.96783

[56] Broberg, L., Thorwid, M. (2015). Evaluation of failure modes for concrete dams. MSc. Thesis. Division of Concrete Structures Stockholm. Sweden.

[57] Mohsin, A.Z., Omran, H., Al-Shukur, A. (2015). Shaking table tests on a physical model of a concrete gravity dam. International Journal of Scientific \& Engineering Research, 6(9): 1230-1238.

[58] Nallanathel, M., Ramesh, B., Raju, P. (2018). Stability analysis of concrete gravity dam (an overview). International Journal of Pure and Applied Mathematics, 119(17): 287-295.

[59] Saqib, M., Ansari, M. (2017). Computation of stresses in concrete gravity dam under seismic loading through ANN and FEM. Procedia Engineering, 173: 1779-1783. http://dx.doi.org/10.1016/j.proeng.2016.12.218

[60] Valtersson, D., Johansson, L. (2018). Stability analysis of non-overflow section of concrete gravity dams: A Longtan dam case study. MSC. Thesis, Luleå University of Technology.

[61] Dawlatzai, K., Dominic, M. (2018). Structural stability and $2 \mathrm{~d}$ finite element analysis of concrete gravity dam. 
International Journal of Engineering Science Invention, 7(1): 09-20.

[62] Pai, S., Biju, P., Ramanujan, J. (2014). Study of response of gravity dam under earthquake acceleration. Transactions on Engineering and Sciences, 2(10): 28-32.

[63] Al-Suhaili, R.H, Ahmed, A.M., Shamil, A.K. (2014). Artificial neural network modeling for dynamic analysis of a dam-reservoir-foundation system. Int. Journal of Engineering Research and Applications, 4(1):121-143.

[64] Ali, A.A., Al-Suhaili, R., Behaya, S. (2014). A genetic algorithm optimization model for the gravity dam section under seismic excitation with reservoir- dam- foundation interactions. American Journal of Engineering Research, 3(6): 143-153.

[65] Saqib, M., Ansari, M., Agarwal, P. (2016). Effectiveness of ANN for seismic behavior prediction considering geometric configuration effect in concrete gravity dams. Perspectives in Science, 8: 432-434. http://dx.doi.org/10.1016\%2Fj.pisc.2016.04.097

[66] Al-Suhaili, R., Ahmed, A.M., Shamil, A.K. (2014). Artificial neural network modeling for dynamic analysis of a dam-reservoir foundation system. Int. Journal of Engineering Research and Applications, 4(1): 121-143.

\section{APPENDIX}

Table 1. Summary of previous researches by this study

\begin{tabular}{|c|c|c|c|c|c|c|}
\hline Researchers & $\begin{array}{l}\text { Gravity Dam } \\
\text { Name }\end{array}$ & $\begin{array}{c}\text { Location of Gravity } \\
\text { Dam }\end{array}$ & Seismic Name & $\begin{array}{c}\text { PGA (Peak Ground } \\
\text { Acceleration) }\end{array}$ & $\begin{array}{l}\text { Type of } \\
\text { Analysis }\end{array}$ & Reference \\
\hline Segura Rocio et al. & - & Canada & - & $0.1 \mathrm{~g}$ to $0.9 \mathrm{~g}$ & $\begin{array}{l}\text { Open } \\
\text { Quake }\end{array}$ & 2 \\
\hline Wieland M. et al. & - & Switzerland & - & $0.1 \mathrm{~g}$ to $0.5 \mathrm{~g}$ & ADINA & 3 \\
\hline VANI M. et al. & Sunkesula & India & Koyna & $0.5 \mathrm{~g}$ & FEM & 4 \\
\hline Dey A. et al. & Pine Flat & $\begin{array}{c}\text { California-United } \\
\text { States }\end{array}$ & Taft ground motion & $\begin{array}{l}0.15 \mathrm{~g} \text { for horizontal } \\
\text { component and } \\
0.083 \mathrm{~g} \text { for the } \\
\text { vertical component }\end{array}$ & GeoStudio & 5 \\
\hline Zeydan B. A. & - & - & El-Centro & - & ANSYS & 6 \\
\hline Esmaielzadeh S. et al. & - & - & $\begin{array}{l}\text { El-Centro } \\
\text { Earthquake }\end{array}$ & $0.3 \mathrm{~g}$ & $\begin{array}{l}\text { Hilbert- } \\
\text { Huang } \\
\text { Method }\end{array}$ & 8 \\
\hline Nayak P. et al. & Koyna dam. & India & - & $0.63 \mathrm{~g}$ & ABAQUS & 9 \\
\hline Zappitelli M. et al. & $\begin{array}{l}\text { Portezuelo del } \\
\text { Viento }\end{array}$ & Mendoza & $\begin{array}{l}21 \text { different ground } \\
\text { motions }\end{array}$ & $\begin{array}{c}0.4 \mathrm{~g}-0.8 \mathrm{~g} \text { with } \\
0.05 \mathrm{~g} \text { increments. }\end{array}$ & ABAQUS & 10 \\
\hline Wang M. et al & $\begin{array}{c}\text { small-scale } \\
\text { model }\end{array}$ & - & $\begin{array}{l}\text { Chinese Code } \\
\text { seismic wave }\end{array}$ & $0.05 \mathrm{~g}-1.4 \mathrm{~g}$ & $\begin{array}{c}\text { Shaking } \\
\text { Table }\end{array}$ & 11 \\
\hline Das R. et al. & Koyna & India & $\begin{array}{l}6.5 \text { earthquake } \\
\text { occurred on } 11 \text { th } \\
\text { December } 1967 \\
\end{array}$ & - & $\begin{array}{l}\text { FEM by } \\
\text { XFEM }\end{array}$ & 12 \\
\hline Zeidan B.A. et al. & Koyna & India & $\begin{array}{c}\text { El-Centro } \\
\text { earthquake }\end{array}$ & - & ANSYS & 13 \\
\hline Mansouri A. et al. & Koyna & Indian & $\begin{array}{l}\text { 6.5-magnitude } \\
\text { earthquake }\end{array}$ & $0.5 \mathrm{~g}$ and $0.35 \mathrm{~g}$ & ABAQUS & 14 \\
\hline Shahir M.E. et al. & - & - & - & $\begin{array}{l}\text { Kabul with PGA } \\
\text { (peak ground } \\
\text { acceleration) } 48 \% \\
\text { g, Herat with PGA } \\
\text { (peak ground } \\
\text { acceleration) } 28 \% \mathrm{~g}\end{array}$ & ANSYS & 15 \\
\hline Mandal K. et al. & - & - & Centro earthquake & - & FEM & 16 \\
\hline Aldemir A. et al. & Melen & Istanbul & $\begin{array}{c}\text { First seismic zone@ } \\
\text { (TEC2007) }\end{array}$ & - & $\begin{array}{c}\text { Pseudo- } \\
\text { Dynamic } \\
\text { Testing } \\
\end{array}$ & 17 \\
\hline Banerjee A. et al. & - & - & - & $0.2 \mathrm{~g}$ & $\begin{array}{l}\text { Westergaa } \\
\text { rd's } \\
\text { Approach } \\
\text { and the } \\
\text { Acoustic } \\
\text { Element }\end{array}$ & 18 \\
\hline Wang M. et al. & - & china & - & $0.153-0.413 \mathrm{~g}$ & $\begin{array}{l}\text { Shaking } \\
\text { Table }\end{array}$ & 19 \\
\hline Torba M. et al. & - & Rożnów & Jarocin & - & ABAQUS & 20 \\
\hline Shahir M.E et al. & Kabul \& Herat & & & $0.48,0.28$ & ANSYS & 21 \\
\hline Yamaguchi Y. et al. & Koyna & Indian & - & $0.15 \mathrm{~g}$ and $0.30 \mathrm{~g}$ & DIANA & 22 \\
\hline Banerjee A. et al. & - & $\begin{array}{c}1080 \text { number of } \\
\text { dams }\end{array}$ & Eurocode 8 (1994) & $0.36 \mathrm{~g}$ & ABAQUS & 23 \\
\hline
\end{tabular}

To be continue... 


\begin{tabular}{|c|c|c|c|c|c|c|}
\hline Researchers & $\begin{array}{l}\text { Gravity Dam } \\
\text { Name }\end{array}$ & $\begin{array}{c}\text { Location of Gravity } \\
\text { Dam }\end{array}$ & Seismic Name & $\begin{array}{c}\text { PGA (Peak Ground } \\
\text { Acceleration) }\end{array}$ & $\begin{array}{c}\text { Type of } \\
\text { Analysis }\end{array}$ & Reference \\
\hline Zheng X. et al. & - & - & $\begin{array}{l}\text { NorthRidge, } \\
\text { Imperial valley, } \\
\text { Friulli, Kobe, } \\
\text { Sakaria, Koyna, } \\
\text { Artificial wave }\end{array}$ & $0.628-0.15$ & $\begin{array}{c}\text { ABAQUS } \\
\text { increment } \\
\text { al } \\
\text { dynamic } \\
\text { analysis } \\
\text { method }\end{array}$ & 24 \\
\hline Mohsin A. Z. & - & - & - & $0.6 \mathrm{~g}$ & ANSYS & 25 \\
\hline Shuai Li et al. & $\begin{array}{l}\text { Corra Linn, } \\
\text { Chinese dam }\end{array}$ & $\begin{array}{c}\text { Canad, Jinshajing } \\
\text { River }\end{array}$ & Loma Prieta record & $\begin{array}{c}0.5527,0.2988 \\
0.1438,0.0571 \mathrm{~g}\end{array}$ & $\begin{array}{l}\text { Shaking } \\
\text { Table, } \\
\text { ABAQUS }\end{array}$ & 26 \\
\hline GANJI H.T et al & $\begin{array}{c}\text { Pine Flat gravity } \\
\text { dam }\end{array}$ & United States & - & $\begin{array}{c}0.18 \mathrm{~g}, 0.27 \mathrm{~g}, \text { and } \\
0.45 \mathrm{~g}\end{array}$ & ABAQUS & 27 \\
\hline Jiang S. et al. & Koyna & Indian & $\begin{array}{c}\text { Koyna earthquake } \\
\text { on December 11, } \\
1967\end{array}$ & - & ABAQUS & 28 \\
\hline Phansri B. et al. & & - & - & $0.25 \mathrm{~g}$ and $0.42 \mathrm{~g}$ & $\begin{array}{l}\text { Shaking } \\
\text { Table }\end{array}$ & 29 \\
\hline SOYSAL B.F. & Melen Dam & & - & $1.497-0.110$ & $\begin{array}{c}\text { DIANA, } \\
\text { Shaking } \\
\text { Table }\end{array}$ & 30 \\
\hline CAI Q. & $\begin{array}{c}\text { NW-IALAD, } \\
\text { Koyna Dam, } \\
\text { Van Ryneveld's } \\
\text { Pass } \\
\end{array}$ & - & - & - & $\begin{array}{l}\text { LUSAS } \\
\text { and } \\
\text { DIANA }\end{array}$ & 31 \\
\hline Sevim B & - & - & Loma Prieta & 0.48 & ANSYS & 32 \\
\hline \multirow[t]{2}{*}{ Falco A. et al. } & Italian & - & $\begin{array}{c}\text { earthquake of } \\
\text { Central Italy of } \\
\text { October 30th 2016 } \\
\end{array}$ & - & $\begin{array}{c}\text { COMSOL } \\
\text { Multiphys } \\
\text { ics } \\
\end{array}$ & 33 \\
\hline & Koyna & china & & $0.3 \mathrm{~g}$ & DIANA & 34 \\
\hline Souri A. et al. & Pine Flat Dam & United States & $\begin{array}{l}\text { Taft Lincoln } \\
\text { earthquake }\end{array}$ & $0.179 \mathrm{~g}$ & $\begin{array}{c}\text { EAGD- } \\
\text { 84, DEDA } \\
\text { approach } \\
\end{array}$ & 35 \\
\hline Issa A.S. et al. & FortisBC Dam & $\begin{array}{l}\text { southern British } \\
\text { Columbia, Canada }\end{array}$ & Loma Prieta record & - & $\begin{array}{l}\text { Shaking } \\
\text { Table, } \\
\text { ABAQUS }\end{array}$ & 37 \\
\hline Karabulut M. et al. & Boyabat & $\begin{array}{c}\text { Duragan county } \\
\text { center }\end{array}$ & $\begin{array}{c}\text { Kocaeli } \\
\text { Earthquake }\end{array}$ & $0.23 \mathrm{~g}$ & ANSYS & 38 \\
\hline Joghataie A. et al & Koyna & Indian & $\begin{array}{c}\text { El Centro\& sakaria } \\
\text { and Tabas } \\
\text { earthquakes } \\
\end{array}$ & - & ANN & 39 \\
\hline Elprince M.R. et al. & Koyna & Indian & $\begin{array}{c}\text { El- Centro } \\
\text { Earthquake }\end{array}$ & 0.35 & ANSYS & 40 \\
\hline Naseri F. et al & Pine Flat Dam & - & $\begin{array}{c}\text { Loma Prieta, Friuli, } \\
\text { Hollister, Imperial } \\
\text { Valley, Kobe, } \\
\text { Landers, }\end{array}$ & - & ABAQUS & 41 \\
\hline Zeydan B. A. & - & - & El-Centro N-S & - & ANSYS & 42 \\
\hline Khiavi M.P. & $\begin{array}{l}\text { Koyna and Pine } \\
\text { Flat dam }\end{array}$ & India, & $\begin{array}{l}\text { El Centro } \\
\text { earthquake }\end{array}$ & $0.34 \mathrm{~g}$. & FEM & 43 \\
\hline Çavuşli M. et al. & Boyabat & Turkey & Duzce & - & ANSYS & 44 \\
\hline Opan M. & - & - & - & $0.1 \mathrm{~g}$ and $0.4 \mathrm{~g}$. & SAP2000 & 45 \\
\hline Yunwei D. et al. & Pine Flat Dam & California & $\begin{array}{c}\text { Taft Earthquake } \\
\text { data, } 1999\end{array}$ & $\begin{array}{c}\text { horizontal }=1.8 \mathrm{~g}, \\
\text { vertical }=1 \mathrm{~g}\end{array}$ & ABAQUS & 46 \\
\hline Khiavi M.P. & Koyna & Indian & $\begin{array}{l}\text { El Centro } \\
\text { earthquake }\end{array}$ & - & FEM & 47 \\
\hline Zeidan B.A. & - & - & $\begin{array}{c}\text { El-Centro N-S } \\
\text { record of Imperial } \\
\text { Valley earthquake } \\
(1940)\end{array}$ & - & ANSYS & 48 \\
\hline Reddy M. et al. & Nagarjunasagar & - & ELCENTRO & $0.332 \mathrm{~g}$ & SAP 2000 & 49 \\
\hline Rozaina I. et al. & Sg. Kinta & Ipoh & E1 Centro & $0.50 \mathrm{~g}$ & LUSAS & 50 \\
\hline WANG D. et al. & - & - & EI Centro & - & ADINA & 51 \\
\hline
\end{tabular}




\begin{tabular}{|c|c|c|c|c|c|c|}
\hline Researchers & $\begin{array}{l}\text { Gravity Dam } \\
\text { Name } \\
\end{array}$ & $\begin{array}{c}\text { Location of Gravity } \\
\text { Dam }\end{array}$ & Seismic Name & $\begin{array}{c}\text { PGA (Peak Ground } \\
\text { Acceleration) }\end{array}$ & $\begin{array}{c}\text { Type of } \\
\text { Analysis } \\
\end{array}$ & Reference \\
\hline Tanooja C. et al & Totladoh dam & India & $\begin{array}{l}\text { seismic design and } \\
\text { the values given in } \\
\text { the IS 1893:2002 }\end{array}$ & 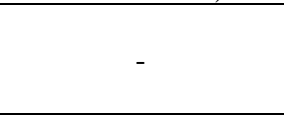 & $\begin{array}{l}\text { Analysis } \\
\text { Method }\end{array}$ & 52 \\
\hline Mowafy M.H. & - & - & $\begin{array}{l}\text { Northridge } \\
\text { earthquake }\end{array}$ & $\begin{array}{l}0.1 \mathrm{~g} \text { to } 0.9 \mathrm{~g} \text { with an } \\
\text { increment of } 0.1 \mathrm{~g}\end{array}$ & ADINA & 53 \\
\hline Deepika $\mathrm{M}$ et al. & - & - & - & $\begin{array}{c}\text { five times the } \\
\text { magnitude of Koyna } \\
\text { earthquake }\end{array}$ & $\begin{array}{l}\text { STAAD- } \\
\text { PRO }\end{array}$ & 54 \\
\hline Bendapudi H. et al. & Koyna & India & Koyna & $\begin{array}{c}0.5 \mathrm{~g} \text { horizontal and } \\
0.3 \mathrm{~g} \text { vertical }\end{array}$ & ABAQUS & 55 \\
\hline Broberg L. et al. & - & - & - & - & $\begin{array}{c}\text { BRIGAD } \\
\text { E }\end{array}$ & 56 \\
\hline Mohsin A.Z. et al. & - & - & - & $0.15 \mathrm{~g}, 0.3 \mathrm{~g}, 0.6 \mathrm{~g}$ & $\begin{array}{c}\text { Shaking } \\
\text { Table, } \\
\text { ANSYS } \\
\end{array}$ & 57 \\
\hline Nallanathel M. et al. & - & Rożnów & Central Europe & - & ABAQUS & 58 \\
\hline Saqib M. et al. & - & - & $\begin{array}{l}17 \text { Different } \\
\text { Earthquake }\end{array}$ & - & $\begin{array}{c}\text { ANN, } \\
\text { ABAQUS } \\
\end{array}$ & 59 \\
\hline Valtersson D. et al. & Longtan & China & - & - & GeoStudio & 60 \\
\hline Dawlatzai K. et al. & Koyna & Indian & - & $\begin{array}{l}0.05 \mathrm{~g} \text { for vertical } \\
\text { and } 0.1 \text { for } \\
\text { horizontal }\end{array}$ & $\begin{array}{l}\text { ANSYS } \\
\text { and } \\
\text { manual } \\
\text { analysis }\end{array}$ & 61 \\
\hline Pai S. et al. & - & - & $\begin{array}{c}\text { Koyna Nagar } \\
\text { earthquake of } 1967\end{array}$ & - & ANSYS & 62 \\
\hline Al-Suhaili R.H et al. & - & - & - & $0.1,0.2$ and 0.3 & $\begin{array}{l}\text { ANN\& } \\
\text { ANSYS }\end{array}$ & 63 \\
\hline Ali A.A. et al. & $\begin{array}{c}30000 \text { Different } \\
\text { model }\end{array}$ & - & - & - & ANN & 64 \\
\hline Saqib M. et al. & - & - & FEMA-P695,2009 & - & $\begin{array}{l}\text { ABAQUS } \\
\text {, ANN }\end{array}$ & 65 \\
\hline Al-Suhaili R. et al. & - & - & - & $\begin{array}{c}\text { horizontal } \\
0.1,0.2,0.3 \text {-vertical } \\
0.05,0.15,0.25 \\
\end{array}$ & $\begin{array}{c}\text { ANN, } \\
\text { ANSYS }\end{array}$ & 66 \\
\hline
\end{tabular}

